\title{
Decision Support Systems to Manage Water Resources for Irrigation at District Level in Southern Italy Using Remote Sensing Information. An Integrated Project
}

\author{
Michele Rinaldi (Scientific Coordinator) \\ Consiglio per la Ricerca e la Sperimentazione in Agricoltura - Unità di Ricerca per i Sistemi Colturali \\ degli Ambienti caldo-aridi (CRA-SCA) - Via Celso Ulpiani 5, 70125 Bari, Italy
}

In this number of the Italian Journal of Agronomy, ten scientific papers are published on the results obtained from the AQUATER project (along with one keynote), which were presented during a final conference held in Bari, Italy on 12-13 May 2009.

The rationale of this project, supported by Ministry of Agriculture, Food and Forestry policies in the framework of Research and Development for areas of Southern Italy, is based on the consideration that the availability of irrigation water for agriculture is becoming ever more limited due to climate change, a deterioration in water quality and an increase in irrigated areas. Consequently, agricultural research must provide guidelines and products in order to achieve the sustainable use of such an important natural resource.

New instruments and technologies are now available to manage the use of water in agriculture more effectively. Remote sensing (RS) can be used to obtain information about land use, vegetation status, soil moisture, surface roughness and, more generally, to estimate crop and soil information also for applied studies on plant nutrition, plant protection and precision agriculture. Different methods have been developed to estimate evapotranspiration from RS data using energy balance equations and thermal infra-red information. Basic and applied knowledge about crop water requirements are well documented, but water distribution authorities require tools and support to manage water in the best way at district level. Crop simulation models are mathematical representations of the soil-plant-atmosphere system involving interaction between biological factors and the environment. Spatially distributed models can be used also in basin, watershed or regional simulations. In the AQUATER project, a variety of tools and methodologies were used such as remote sensing images, soil and land use maps at different spatial and temporal scales, geostatistical methodologies, geographic information systems, ground truth measurements, land use, canopy and soil temperature, soil and plant water status, normalized difference vegetation index, crop water stress index, leaf area index, actual evapotranspiration, crop coefficients, crop yield, agroecological indicators and crop simulation models.

In Italy, an efficient management of water resources is crucial, particularly for southern areas which are characterized by a Mediterranean climate, in order to improve the economic and environmental sustainability of agricultural activity.

The innovative aspect of this project is that of linking remote sensing information with soil and plant information and crop simulation models to set up a decision support system (DSS) aimed towards establishing the best water management practices for district level irrigation.

The project was divided into four work packages: remote sensing and image analysis, cropping systems, modelling and software development and stakeholders.

The following research institutions were partners of the project:

- Consiglio per la Ricerca e la Sperimentazione in Agricoltura. Unità di Ricerca per i Sistemi Colturali degli Ambienti caldo-aridi, Bari (coordinator);

- Consiglio Nazionale delle Ricerche - Istituto di Studi sui Sistemi Intelligenti per l'Automazione, Bari; 
- Università di Napoli "Federico II" - Dipartimento di Ingegneria Agraria e Agronomia del Territorio;

- Università di Milano - Dipatimento di Produzione Vegetale.

The project was organized in three areas which represent vital water districts in both southern and national agriculture: Capitanata, Ionic coastal and Sele river plains.

Capitanata. The second largest plain in Italy (about $4000 \mathrm{~km}^{2}$ ). The most widespread crops are winter wheat (rainfed), sugar beet, tomato, vegetables, grapevine and olive orchards. The climate is semi-arid, with hot and dry summers (annual rainfall is about $550 \mathrm{~mm}$ ) and short and temperate winters.

An irrigation scheme (Consorzio per la Bonifica della Capitanata) provides the irrigation water for most of the area that is characterized by clay and deep soils. The most frequently used irrigation methods are drip and sprinkler systems.

Ionic coastal. This plain (about $800 \mathrm{~km}^{2}$ ) includes the Basilicata and Puglia regions and faces the Ionic sea. It is characterised by hills with a gentle descent towards the sea. The soils are clay and silty-clay on the inner part of the plain and sand or silty-sand in the areas close to the sea. The climate is classified as "accentuated thermo-Mediterranean". The most widespread crops are vegetables, orange and olive orchards and grapevine, irrigated by localized and sprinkler methods. The irrigation water is provided by two irrigation schemes.

Sele river. The plain (about $500 \mathrm{~km}^{2}$ ) is split between the right and left banks of the Sele river. The soils are mainly clay-loam and silty-clay, of volcanic origin. The main crops are maize, forage, potatoes, vegetables (artichokes, lettuce, cucurbits, pepper, tomato), peaches, apricots and pear orchards. Irrigation is applied from May to September. Two irrigation schemes provide the irrigation water.

A series of intermediate and final conferences, operative meetings and training courses about irrigation were organized during the project. Extensive information and a breakdown of the principal results are available on the project home web page (http://aquater.entecra.it).

My special thanks go to the Ministry of Agriculture for supporting the project, to the CRA for help in project management and to all those people who have worked so diligently to ensure the good success of the research. 